\title{
Why Aren't Political Scientists Interested in Native American Politics?
}

\author{
Paul Frymer
}

1 ennan Ferguson asks why "political science hates American Indians" and proffers many important and necessary explanations. I hope his essay sparks a real conversation in the profession and I appreciate this opportunity to participate in the discussion.

First, Ferguson is convincing that the discipline remains unreflectively dominated by the ideological assumptions and agendas of white men. At the same time, I am not sure political science is so ideologically active, specific, or coherent in its exclusion of Native American voices and subjects. Certainly, in the discipline's earliest years, leading political scientists like A. Lawrence Lowell and Woodrow Wilson (both were APSA presidents) embraced the dominant views of the nation's settler state, views that remain deeply embedded today. ${ }^{1}$ But in the current context, this ideological imposition has been in many ways replaced by methodological fetishism. The majority of political scientists do not seemingly care about Native Americans any more than they do many other substantive categories of marginalized groups that exist outside of formal governing power structures, from workers and women to environmentalists and animal rights activists. Scholars of American politics tend to cluster around a small set of research topics, often chosen because of the ease with which such topics can be studied with formal and quantitative methods. These privileged methodologies of the discipline are, of course, not ideologically or politically neutral; and they flourish because they rarely challenge existing orthodoxies. Focusing on formally chosen political elites forecloses communities that are disadvantaged, less visible, and at the political margins. To the degree that many in the profession are not cognizant of such relationships between ideology, subject matter, and methodological practice, Ferguson does a great service by forcing us to examine the underlying assumptions.

When substantive interests do get covered within the disciplinary journals, they tend to be driven by events in the

Paul Frymer is the Director of the Program in Law and Public Affairs at Princeton University (pfrymer@princeton. edu). nation's current-day headlines. The civil rights movement eventually led to the increased study of African Americans in political science; recent work on GLBT communities reflects the movement activism of the last few decades. Current work on economic inequality and incarceration has begun to flourish in response to astounding societal disparities. This attention to current concerns is critical and important, but it often forces social movements to do the work of making our discipline aware. And the cost is that, as Professor Ferguson notes, too frequently the discipline has stopped looking for what is missing and the underlying political structures that have enabled these erasures in the first place. At a time when the newest technological and methodological advances are celebrated for their empirical precision, we ought to hold onto older theoretical debates and methods that emphasized and enabled unearthing what is hidden.

Without a desire to exaggerate, Ferguson does miss a recent revival of interest in Native American politics, particularly in my own field of American political development where concerns with temporality and ideological construction are central to the field. As such, this interest draws in part from the explosion of research among historians who have placed Native Americans at the center of North American state formation, while addressing critical political questions about the forms and mechanisms of imperial authority, racial creation, and the construction of state communities and borders. ${ }^{2}$ Some of these scholars are building on the critical legacy of Michael Paul Rogin, with the goal of reconceptualizing American state building both as an imperial project and settler state. ${ }^{3}$ Others have focused on the importance of Indian conflicts and incorporation for the emergence of federal administrative capacities. ${ }^{4}$ New work on citizenship and westward development has imaginatively reconstructed important elements of state formation and the need of establishing political authority, while others are following the influential work of Rogers Smith and Ronald Takaki in bringing Native Americans more fully into our understanding of racial formation in the United States. 5

It's only a start. Ferguson is right that we have a long way to go. 


\section{Notes}

1 See, e.g., Lowell 1899; Wilson 1893.

2 See, e.g., Ablavsky 2014; DeLay 2008; Hämäläinen 2008; Limerick 1987; Reséndez, 2004; Richter 2001; White 1991.

3 Bruyneel 2008; Frymer 2014; Heumann 2009; Maass 2014; Rana 2010; Rogin 1975.

4 See, e.g., Carpenter 2016; Ericson 2011; Jensen 2003; Rockwell 2013; Rubin 2015.

5 See, e.g., Hochschild and Marea 2008; Obert 2014; Opal 2013; Schroedel and Hart 2015; Smith 1997; Takaki 1980.

\section{References}

Ablavsky, Gregory. 2014. "The Savage Constitution." Duke Law Journal 63: 999-1213.

Bruyneel, Kevin. 2008. "Hierarchy and Hybridity: The Internal Postcolonialism of Mid-Nineteenth-Century American Expansionism." In Race and American Political Development, ed. Joseph Lowndes et al. New York: Routledge.

Carpenter, Daniel. 2016. "On the Origins of the Administrative Petition: Innovations in Nineteenth-Century Native America." In Administrative Law from the Inside Out: Essays on Themes in the Work of Jerry Mashaw, ed. Nicholas Parrillo. New Haven, CT: Yale University Press.

DeLay, Brian. 2008. War of a Thousand Deserts: Indian Raids and the U.S.-Mexican War. New Haven, CT: Yale University Press.

Ericson, David F. 2011. Slavery in the American Republic: Developing the Federal Government, 1791-1861. Lawrence: University of Kansas Press.

Frymer, Paul. 2014. "'A Rush and a Push and the Land Is Ours': Territorial Expansion, Land Policy, and U.S. State Formation." Perspectives on Politics 12(1): 119-44. Hämäläinen, Pekka. 2008. The Comanche Empire. New Haven, CT: Yale University Press.

Heumann, Stefan. 2009. "The Tutelary Empire: State and Nation Building in the 19th Century United States." Ph.D. diss., University of Pennsylvania.

Hochschild, Jennifer L. and Brenna Marea. 2008. "Racial Reorganization and the United States Census 18501930: Mulattoes, Half-Breeds, Mixed Parentage, Hindoos, and the Mexican Race." Studies in American Political Development 22(1), 59-96.

Jensen, Laura. 2003. Patriots, Settlers, and the Origins of American Social Policy. New York: Cambridge University Press.
Limerick, Patricia Nelson. 1987. The Legacy of Conquest: The Unbroken Past of the American West. New York: W. W. Norton.

Lowell, Lawrence A., "The Colonial Expansion of the United States," The Atlantic Monthly 83 (February 1899), 145-146.

Maass, Richard W. 2014. "Beasts of Prey: American Annexationism and Native American Lands," (Paper presented at the American Political Science Association, Washington, D.C.).

Obert, Jonathan. 2014. "The Six-Shooter Marketplace: 19th Century Gunfighting as Violence Expertise." Studies in American Political Development 28(1): 49-79.

Opal, J. M. 2013. “General Jackson's Passports: Natural Rights and Sovereign Citizens in the Political Thought of Andrew Jackson, 1780s-1820s." Studies in American Political Development 27(2): 69-85.

Rana, Aziz. 2010. The Two Faces of American Freedom. Cambridge: Harvard University Press.

Reséndez, Andrés. 2004. Changing National Identities at the Frontier: Texas and Mexico, 1800-1850. New York: Cambridge University Press.

Richter, Daniel K. 2001. Facing East from Indian Country: A Native History of Early America. Cambridge: Harvard University Press.

Rockwell, Stephen J. 2013. Indian Affairs and the Administrative State in the Nineteenth Century. New York: Cambridge University Press.

Rogin, Michael Paul. 1975. Fathers and Children: Andrew Jackson and the Subjugation of the American Indian. New York: Knopf.

Rubin, Ruth Bloch. 2015. "Reservation Care: The Political Origins of American Indian Healthcare.” Unpublished manuscript, [University of Chicago].

Schroedel, Jean and Ryan Hart. 2015 "Vote Dilution and Suppression in Indian Country." Studies in American Political Development 29(1): 40-67.

Smith, Rogers M. 1997. Civic Ideals. New Haven, CT: Yale University Press.

Takaki, Ronald. 1980. Iron Cages. New York: Oxford University Press.

White, Richard. 1991. The Middle Ground: Indians, Empires, and Republics in the Great Lakes Region, 1650-1815. New York: Cambridge University Press.

Wilson, Woodrow. 1893. "Mr. Goldwin Smith's 'Views' on Our Political History." The Forum, December, 489-99. 